\title{
Enhancing Water Productivity in Agriculture at Fokshingkot Lift Irrigation System
}

\author{
Dinesh Rajouria and Padma Prasad Aryal
}

Padma Prasad Aryal

\begin{abstract}
Ranibas village of Foksingkot Village Development Committee (VDC), Palpa District, Nepal is a severe water scarce area. The nearest water source is spring water about 2.5 hours walk downhill (to and fro) to fetch a vessel of water and it is three hours for the farthest household of the area. A lift pumping system consisting of three stages, each of $100 \mathrm{~m}$ lift and the fourth of $30 \mathrm{~m}$ lift was (with total lifting of $330 \mathrm{~m}$ ), was constructed to deliver 1.94 liters per sec (l/sec) water for drinking purpose as well as for irrigation of five hectare of land. Despite failures of several lift pumping schemes for irrigation in Nepal, this high head lifting/pumping system has been successful. The 102 households are benefitted with easy availability of drinking water and also for irrigation with drip and sprinkler systems. The lift water supply system has helped in saving time of children and women for fetching water and also increased household income by farming supported by irrigation. The virtual labor saving value of one year surpasses the investment of the project.
\end{abstract}

\section{Key words: Lift irrigation, high head pumping, low water required crops, Nepal}

\section{Introduction}

D anibas village of Fokshingkot VDC is located at Rabout $26 \mathrm{~km}$ northeast from Tansen Municipality, the headquarters town of Palpa District, Nepal. Further, it is close to the 5.1 MW power house site of the Andhi Khola Hydropower Plant.

Basically, in a rural area, migration and poverty mitigation depends upon agricultural production probability. Scarcity of water for drinking and irrigation creates a fundamental concern and demands the need of a better approach, both for survival and livelihood. Marginalized land can be converted into productive land by providing irrigation through the adoption of various non-conventional technologies. Even a small spring source can be efficiently utilized to provide irrigation to the upland. Wherever possible gravity flow can be practiced through pipes, but lifting can also be a very good where electricity is available.

There are 102 households in the target area where a high lift water pumping system is installed for multipurpose use of drinking water and irrigation. The project area lies at about 1000m above mean sea level and is marginalized land. An irrigation system with multiple uses at Fokshingkot VDC is one of the best examples of providing irrigation water to the marginalized land.

Before the intervention of the project this community of 102 households faced acute shortage of water, as there was only one source downhill from the settlement. It used to take 2.5 hours to and fro to get a vessel of water from the nearest house and almost three hours from the farthest house. The healthiest adult could carry 20 liters of water at a time. People used to get up at around 4 o'clock a.m. to walk down the hill to join the queue to fetch. Even children were not spared, as they joined their parents to carry water up to their homes in order to meet domestic demand for the whole day and night until the next morning.

Almost every adult and old people involved in carrying water had some kind of complaint about their back. And, due to the hardship of fetching water, the community was forced to compromise with cleanliness.
It is reported that every household used to spend on an average 4.5 hours fetching water. Consider the Nepalese wage of Rs. 150 per day, and the 4.5 hours wage for fetching water is equivalent to Rs. 87.30. Therefore, the total value per month is NRs. 2,531.25 per household. The net value for 102 households for one year comes out to be Rs. 3,098,250.00 (about US $\$ 39,218$ ). It is evident that the virtual labor value of one year surpasses the total investment of the project.

The micro non-conventional lift irrigation system of Fokshingkot has also had an impact on the migration of inhabitants and has enhanced their livelihood making them relatively more healthy and wealthy. The population now not only has access to clean drinking water for household use, but also has water for irrigation to grow vegetables on the commercial basis. Hence, the Fokshingkot micro-irrigation system can be considered as a model system, one that addresses socio-economic status promotion of hill populations and optimum utilization of water resources along with the water management mechanism.

\section{Background of the Project}

The Ranibas non-conventional lift irrigation system is one of the model irrigation systems in Nepal, developed by funding from the Non-Conventional Irrigation Technology Project (NITP) under the Department of Irrigation (DOI), Nepal with users' initiative and active participation in Ranibas, Ward 4, Fokshingkot Village Development Committee (VDC) of Palpa District. Construction started on March 19, 2006 and was completed by October 05, 2007, drawing water up from the spring, which is about $330 \mathrm{~m}$ below the village.

There are all together four lifts; three of $100 \mathrm{~m}$ each and one of 30m. The first three pump sets are $4.5 \mathrm{~kW}$ capacity of each, whereas the fourth one is $2.0 \mathrm{~kW}$. There are also three collection tanks with the submersible pump laid inside. Each one pumps the water to their upper tank. From the third tank water is pumped to the two Thai Jars made of ferrocement with a capacity of 2000 
liters each. Every household has a tap from which they get their water for drinking and irrigation. The system is called Ranibas Non-Conventional Irrigation System. It is designed to provide water for domestic use at the rate of 15 liters per capita per day to all 102 households, and to irrigate about 5 hectors of land in Ward 4 of Ranibas village. To manage the system, the users have established the Ranibas Non-Conventional Irrigation Water Users Association.

The irrigation water requirement was assessed for cabbage (October-January), cucumber (February-May) and tomato (June- September). The irrigation water requirement assessment showed, however, that there is no need to irrigate tomatoes, as the rainfall is sufficient during the cropping period.

The highest water demand is found to be in the month of April with 4,954.4 $\mathrm{m}^{3}$ requiring the lower most pump to operate 24 hours. This has been the basis for deciding the discharge capacity of the pump. The total cost of the project at its completion is shown in Table 1.

\section{The Water Source}

The spring water that ultimately flows down to the

\begin{tabular}{|l|c|}
\hline $\begin{array}{c}\text { Payment and Contribution } \\
\text { (with source) }\end{array}$ & Cost in Nepalese Rupees \\
\hline First package (DOI) & Rs 2,349,920.00 \\
\hline Second package (DOI) & $377,442.00$ \\
\hline Labor contribution (Users) & $407,165.00$ \\
\hline Total Cost & $\begin{array}{r}\text { Rs 3,134,527.00 } \\
\text { (US\$ 39,677.00) }\end{array}$ \\
\hline
\end{tabular}

Table 1. Cost of the Project.

\begin{tabular}{|l|l|}
\hline Households & 102 \\
\hline Population & 600 including school students \\
\hline $\begin{array}{l}\text { Proposed irrigation } \\
\text { command area }\end{array}$ & 5 ha. \\
\hline GI pipe line & 2 inch dia, 442 meter \\
\hline Capacity of Pumps & 3 sets at $4.5 \mathrm{~kW}$ and 1 set at $2.0 \mathrm{~kW}$ \\
\hline Lift & $\begin{array}{l}3 \text { stages of } 100 \mathrm{~m} \text { and one of } 30 \mathrm{~m}, \\
\text { totaling } 330 \mathrm{~m}\end{array}$ \\
\hline Polyethylene pipe line & $6 \mathrm{~km}$ \\
\hline Discharge Rate & 1.94 liters per sec. \\
\hline Taps & 95 no. \\
\hline Meters & 95 no. \\
\hline Pump House & 4 no. \\
\hline Reservoir & 2 no. \\
\hline Plastic tank & 1 no. \\
\hline Pump & 4 no. installed, 1 no. spare \\
\hline $\begin{array}{l}\text { Spring water collection } \\
\text { tank }\end{array}$ & 1 no \\
\hline $\begin{array}{l}\text { Thai Jar (ferrocement } \\
\text { water storage tank) }\end{array}$ & 2 no. \\
\hline
\end{tabular}

Table 2. Salient Feature of the Ranibas Non-Conventional Lift Irrigation System.
Kali Gandaki River is tapped in the cave of the rock in a collection tank 330m below Ranibas village. A pump house is constructed to pump the water 10om up to the second stage pump house. The water is pumped by the submersible pump through two inch GI pipe.

\section{Formation of the Ranibas Non-Conventional Irrigation Water Users' Association}

A representative body was formed and registered in 2006 AD under the Water Resources Act 1992 AD (2049 VS). The executive body has nine members with $33 \%$ women's participation. The executive body has three years tenure, with an election every three years.

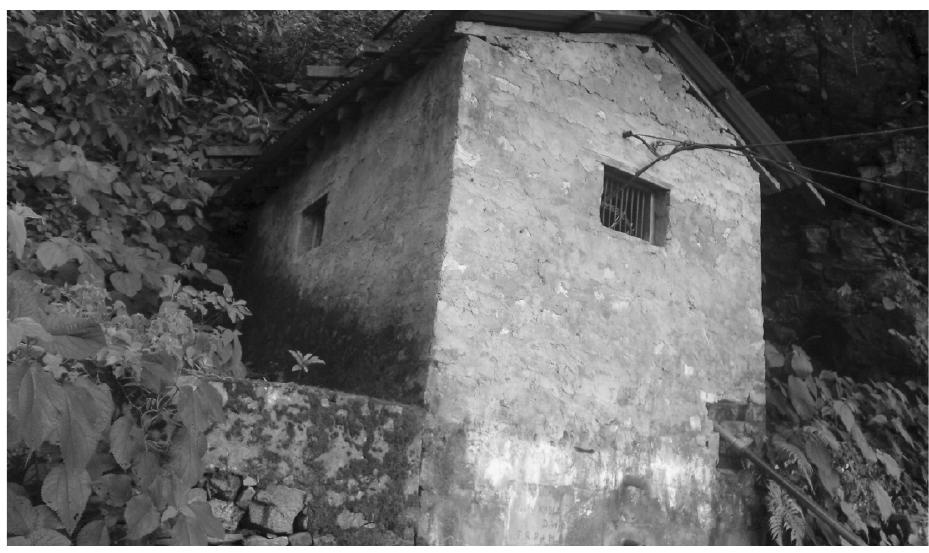

Photo 1. Intake of Water Source and Electric Panel Room

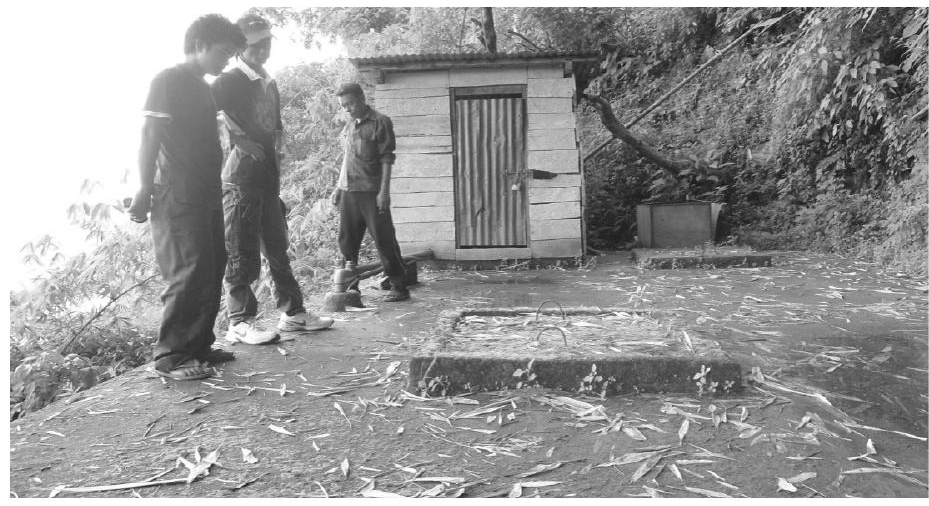

Photo 2. Intermediate Collection Tank, Panel Room and Pipeline

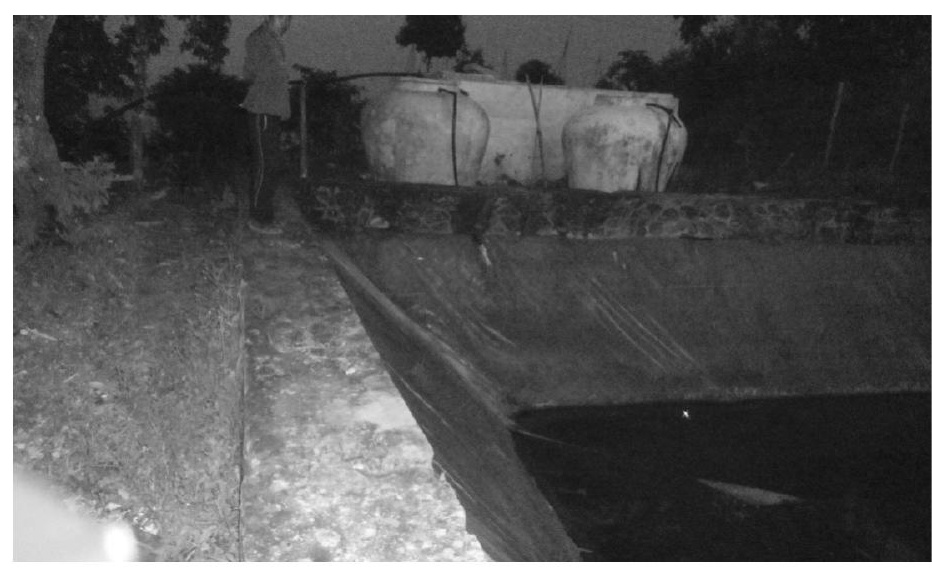

Photo 3. Water Collection Tanks for Drinking and Irrigation Purpose 
In order to pay the electricity charges and meet the minor maintenance requirements, two types of service fee are paid by each household. Every household is supplied with a meter, and each is charged Rs. 90 as a demand charge, plus Rs. 10 per 1,00o liters of water. On average about Rs. 12,000 is collected per month. Rs. 8,500 is paid to the operators, Rs. 2,200.00 is paid as electricity charges and the balance is kept in the maintenance account. According to the report of the users association, the users' service fees run from Rs. 110 to Rs. 230 per month. A defaulter does not get water until he pays his back dues. The income and expenditure statement of last financial year 2010/2011 is given in Table 3.

\section{Irrigation Service Fee}

have more cattle, which in turn not only provides them milk and milk products but also calves (especially bull calves for tilling) and organic manure for better vegetable crop production.

The availability of water also has a direct impact on their health, not only because they are free from drudgery but also through the improved food supplemented by nutritionally fresh vegetables. The availability of water has also great impact on the cleanliness of the surrounding environment and thus has reduced the risk of stomach problems.

This system is also a model system of public-private partnership (the DOI and BPC). The use of advanced technology (submersible pumps) for pumping the water high up to $330 \mathrm{~m}$ is noteworthy. This system is one of the best examples of an inclusive approach towards the optimum utilization of resources-marginal land, water and social coherence. The agencies involved in the development of water resources should draw their attention towards replicating this approach in other part of the country.

\begin{tabular}{|c|c|c|c|}
\hline S.No. & Date & $\begin{array}{c}\text { Income } \\
\text { NRs. }\end{array}$ & $\begin{array}{c}\text { Expenditure } \\
\text { NRs. }\end{array}$ \\
\hline 1. & 2009/2010 (2066 /2067 VS) & $30,122.00$ & \\
\hline 2. & $2010(2067) / 03$ month & $12,140.00$ & $29,948.00$ \\
\hline 3. & $2010(2067) / 04$ month & $10,310.00$ & $9,505.00$ \\
\hline 4 & $2010(2067) / 05$ month & $13,530.00$ & $10,793.00$ \\
\hline 5 & $2010(2067) / 06$ month & $13,860.00$ & $9,478.00$ \\
\hline 6 & $2010(2067) / 07$ month & $14,040.00$ & $9,440.00$ \\
\hline 7 & $2010(2067) / 08$ month & $13,470.00$ & $9,732.00$ \\
\hline 8 & $2010(2067) / 09$ month & $13,340.00$ & $9,818.00$ \\
\hline 9 & $2010(2067) / 10$ month & $13,760.00$ & $10,390.00$ \\
\hline 10 & $2010(2067) / 11$ month & $13,770.00$ & $19,416.00$ \\
\hline 11 & $2010(2067) / 12$ month & $13,320.00$ & $10,173.00$ \\
\hline 12 & 2011 (2068)/01 month & $13,200.00$ & $12,774.00$ \\
\hline 13 & $2011(2068) / 02$ month & $13,390.00$ & $23,589.00$ \\
\hline 14 & $2011(2068) / 03$ month & $12,480.00$ & $9,921.00$ \\
\hline Total & & $200,732.00$ & $174,977.00$ \\
\hline \multicolumn{4}{|c|}{ Total balance is NRs. $25,755.00$ (US\$ 343.40) } \\
\hline
\end{tabular}

Table 3. Income and Expenditure of Fiscal Year 2010/2011 AD (2067-2068 VS).

Dinesh Rajouria, MSc, Water Resources Management, is associated with Department of Irrigation since the last 15 years. He is Senior Divisional Engineer and has planned, designed and implemented many small and medium Irrigation systems. Fokshingkot Non-Conventional Irrigation System was conceived, designed and implemented under his supervision.

Padma Prasad Aryal, B.A. Sociology, is associated with irrigation systems mostly from the water user's perspective. He was

\section{Environment and Health Impacts}

It is said that water is life for all creatures. No one can survive without water. Basically water is used for drinking, washing, irrigation and hydro-electricity generation. For health and sanitation, the role of water is vitally important. Clean water may be counted as medicine, and the availability of clean spring water has reduced the occurrence of many stomach related illness in the households.

\section{Conclusion}

The availability of water in Ranibas village has not only reduced the burden of drudgery but at the same time has brought many opportunities to make life easier and improve the living standard. The households that were reluctant towards cattle rearing are now encouraged to involved in the Andhi Khola irrigation systems run from the water supplied from the 5.1 MW Andhi Khola Hydel Project. He has been General Secretary (for six years) and central committee member (for five years) of the National Federation of Water Users Association of Nepal. Presently, he is involved in the Andhi Khola upgrading Project of Butwal Power Company, Ltd., working as a senior personal relations officer.

Corresponding address: akwuas@yahoo.com

\section{References}

DOI, 2004/o5, Feasibility Study of Fokshingkot NonConventional Irrigation Project, NITP, Dept. of Irrigation, Kathmandu. 